\title{
Chemical analysis of the Alphaproteobacterium strain MOLA1416 associated with the marine lichen Lichina pygmaea
}

\section{Delphine Parrot ${ }^{\mathrm{a}, 1}$}

Laurent Intertaglia

Philippe Jehan

Martin Grube ${ }^{\mathrm{d}}$

Marcelino T. Suzuk

Sophie Tomasi ${ }^{\mathrm{a},}$

sophie.tomasi@univ-rennes1.fr

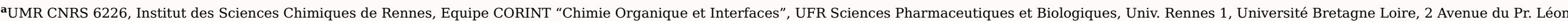

Bernard, F-35043, Rennes, France

borbonne Universités, UPMC Univ Paris 06, CNRS, Observatoire Océanologique de Banyuls (OOB), F-66650, Banyuls/Mer, France

${ }^{\mathbf{c}}$ CRMPO, Université de Rennes 1, 35042, Rennes Cedex, France

dinstitut für Pflanzenwissenschaften Karl-Franzens-Universität Graz, Austria

eSorbonne Universités, UPMC Univ Paris 06, CNRS, Laboratoire de Biodiversité et Biotechnologies Microbiennes (LBBM), Observatoire Océanologique, F-66650, Banyuls/Mer, France

*Corresponding author.

${ }^{1}$ Present address: GEOMAR Helmholtz Centre for Ocean Research Kiel, Research Unit Marine Natural Products Chemistry, GEOMAR Centre for Marine Biotechnology, Am Kiel-Kanal 44, 24106 Kiel, Germany.

Abstract

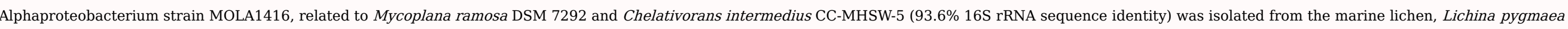

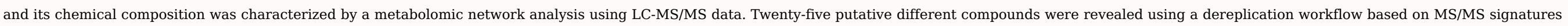

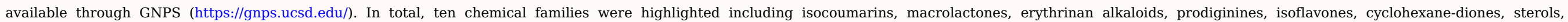

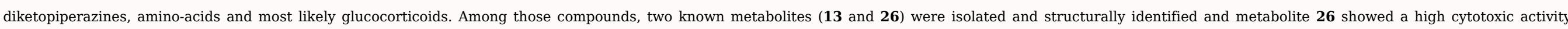
against B16 melanoma cell lines with an $\mathrm{IC}_{50} 0.6 \pm 0.07 \mu \mathrm{g} / \mathrm{mL}$

Keywords: Lichen-associated bacteria; Lichina pygmaea; Alphaproteobacteria; LC/MS ${ }^{\mathrm{n}}$; Dereplication workflow; Molecular networking

\section{Introduction}

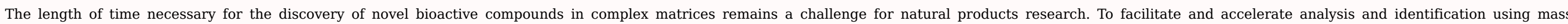

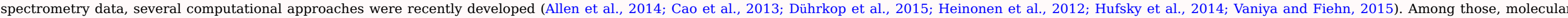

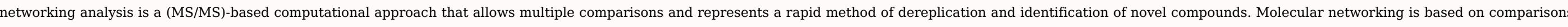

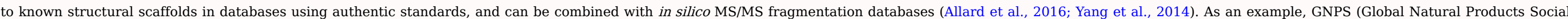




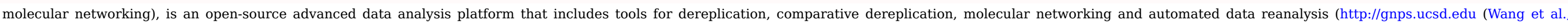
2016). Here, we applied this recently-developed approach to study the chemical profiles of bacterial communities associated with a marine lichen.

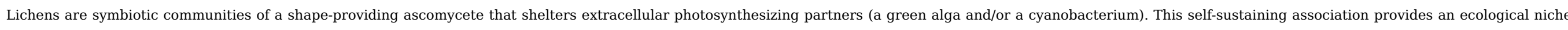

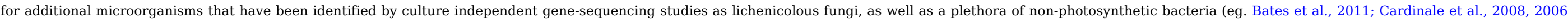

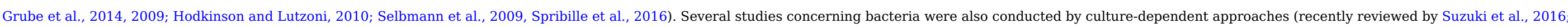

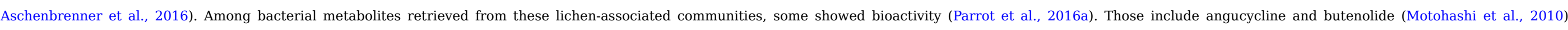

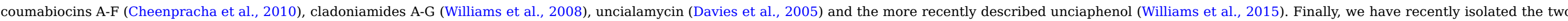
new acrylate compounds, cyaneodimycin and its derivative cyaneomycin, from isolates of Streptomyces cyaneofuscatus MOLA1488 isolated from Lichina confinis (Parrot et al., 2016b).

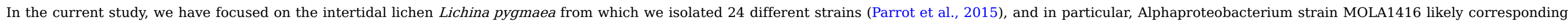

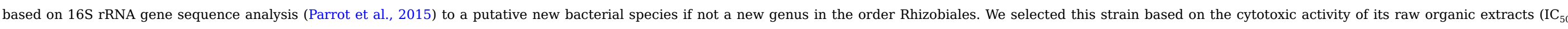

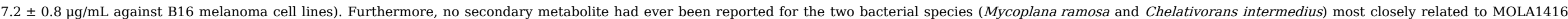

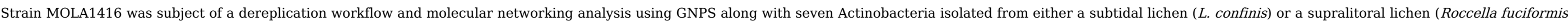

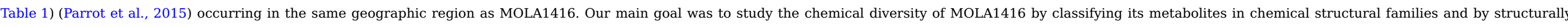
identifying some of these metabolites.

Table 1 Characteristics of bacteria isolated from Lichina pygmaea, L. confinis and Roccella fuciformis (Parrot et al., 2015) used in the molecular networking by GNPS (http://gnps.ucsd.edu). alt-text: Table 1

\begin{tabular}{|c|c|c|c|c|c|c|c|}
\hline Lichens & $\begin{array}{l}\text { Bacterial } \\
\text { strains }\end{array}$ & Genus & $\begin{array}{c}\text { 16S rRNA } \\
\text { similarity (\%) }\end{array}$ & Family & Production of metabolites & $\begin{array}{c}\mathrm{IC}_{50} \text { on B16 cell lines of } \\
\text { AcOE } \frac{t \text { EtOAc extract }}{(\mu \mathrm{g} / \mathrm{mL})}\end{array}$ & References \\
\hline $\begin{array}{l}\text { Lichina } \\
\text { pygmaea } \\
\text { (marine) }\end{array}$ & MOLA1416 & $\begin{array}{l}\text { Mycoplana } \\
\text { ramosa } \\
\text { Chelativorans }^{\mathrm{a}} \\
\text { intermedius }^{\mathrm{a}}\end{array}$ & $\begin{array}{l}93.56 \\
93.56\end{array}$ & $\begin{array}{l}\text { Brucellaceae } \\
\text { Phyllobacteriaceae }\end{array}$ & $\begin{array}{l}- \\
-\end{array}$ & $7.2 \pm 0.8$ & $\begin{array}{l}\text { (Kämpfer et al., 2015; } \\
\text { Urakami et al., 1990) }\end{array}$ \\
\hline \multirow{3}{*}{$\begin{array}{l}\text { Lichina } \\
\text { confinis } \\
\text { (marine) }\end{array}$} & MOLA1488 & $\begin{array}{l}\text { Streptomyces } \\
\text { cyaneofuscatus }\end{array}$ & 100.00 & Streptomycetaceae & $\begin{array}{l}\text { daunomycin, cosmomycin B, galtamycin B, maltophilin, } \\
\text { cyaneodimycin, cyaneomycin, } \\
\text { 3-(hydroxyacetyl) indole, cyclo-(Phe, Pro), cyclo-(L-Leu, L-Pro), } N \text { - } \\
\text { acetyl- } \beta \text {-oxotryptamine, } N \text {-methyldactinomycin, usnic acid }\end{array}$ & $0.33 \pm 0.16$ & $\begin{array}{l}\text { (Braña et al., 2015; Parrot et } \\
\text { al., 2016b) }\end{array}$ \\
\hline & MOLA1448 & $\begin{array}{l}\text { Marmoricola } \\
\text { aequoreus }^{\mathrm{a}}\end{array}$ & 95.04 & Nocardioidaceae & NF & $83 \pm 10$ & - \\
\hline & MOLA1450 & $\begin{array}{l}\text { Micrococcus } \\
\text { luteus }\end{array}$ & 97.93 & Micrococcaceae & lutoside, [3H]-indole acetic acid & $36 \pm 4$ & $\begin{array}{l}\text { (Barazani and Friedman, } \\
\text { 1999; Bultel-Poncé et al., } \\
\text { 1997) }\end{array}$ \\
\hline \multirow{4}{*}{$\begin{array}{l}\text { Roccella } \\
\text { fuciformis } \\
\text { (maritime) }\end{array}$} & MOLA1522 & $\begin{array}{l}\text { Nocardioides } \\
\text { mesophilus }^{\mathrm{a}}\end{array}$ & 94.91 & Nocardioidaceae & teichoic acid, leucylblaticidin, rodaplutin (Nocardioides sp.) & $250 \pm 10$ & $\begin{array}{l}\text { (Dellweg et al., 1988; } \\
\text { Shashkov et al., 1999) }\end{array}$ \\
\hline & MOLA1528 & $\begin{array}{l}\text { Sediminihabitans } \\
\text { luteus }\end{array}$ & 98.43 & Cellulomonadaceae & NF & $>400$ & - \\
\hline & MOLA1554 & $\begin{array}{l}\text { Sediminihabitans } \\
\text { luteus }\end{array}$ & 98.07 & Cellulomonadaceae & NF & $215 \pm 35$ & - \\
\hline & & Microbacterium & & & & & \\
\hline
\end{tabular}


a Putative new species based on 16S rRNA gene sequence analysis (identity $\leq$ at 97\%); NF: not found.

\section{Results and discussion}

\subsection{Molecular networking and dereplication approaches}

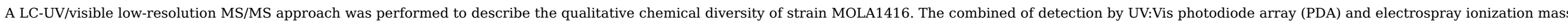

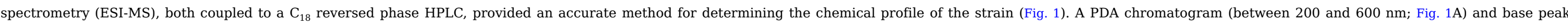

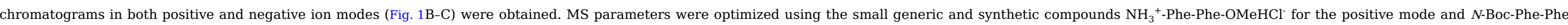

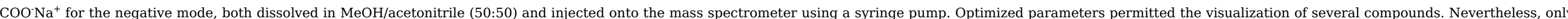
the positive mode was considered subsequently as it allowed the detection of a larger number of compounds.

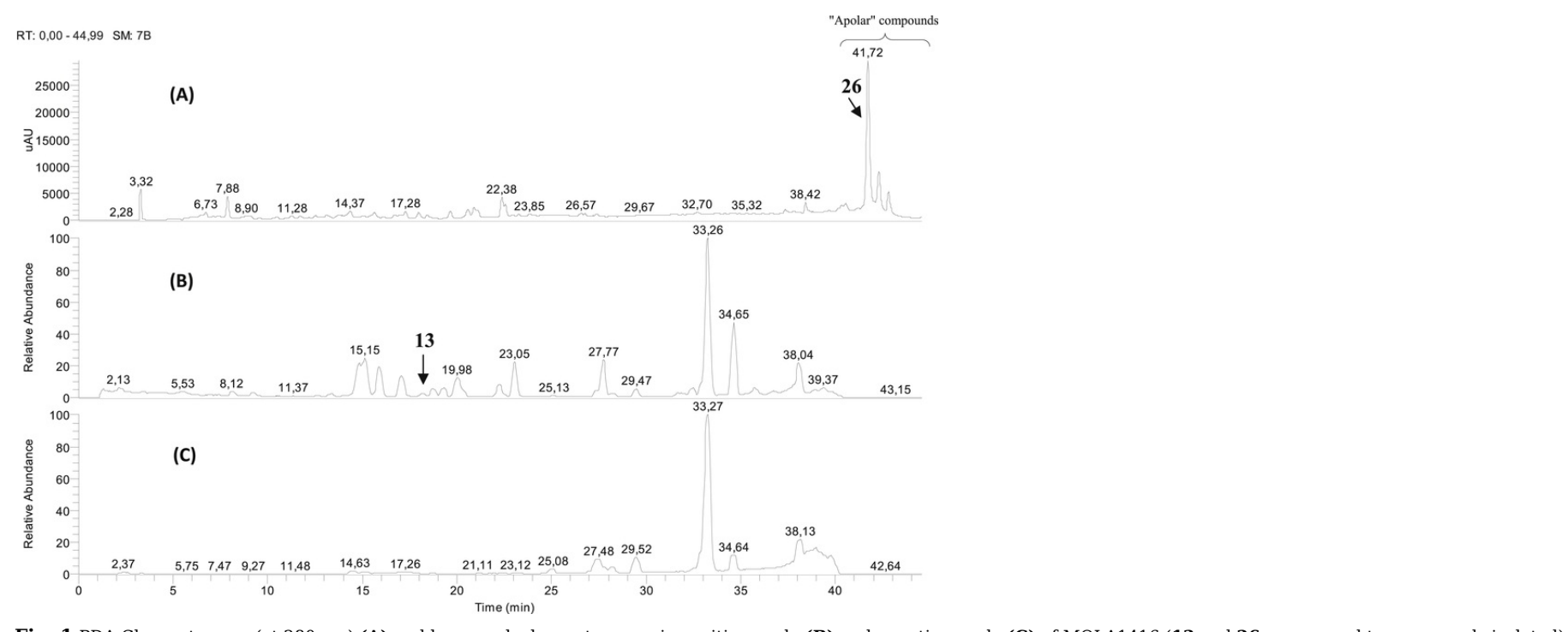

Fig. 1 PDA Chromatogram (at $280 \mathrm{~nm}$ ) (A) and base peak chromatograms in positive mode (B) and negative mode (C) of MOLA1416 (13 and 26 correspond to compounds isolated). alt-text: Fig. 1

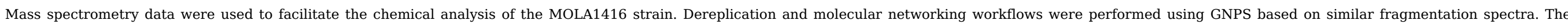

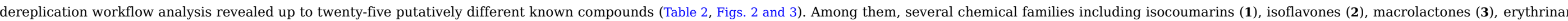

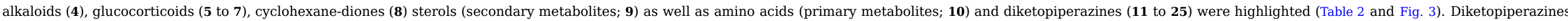

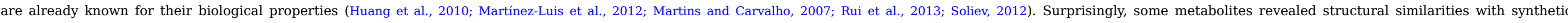

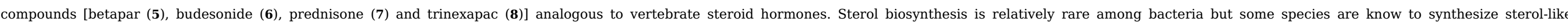

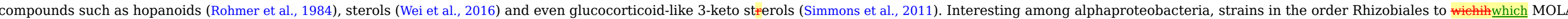

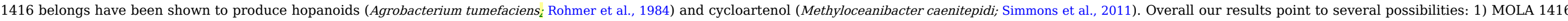

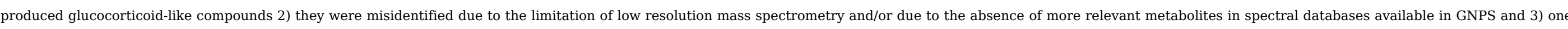

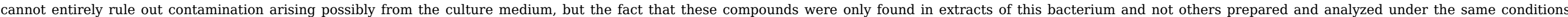




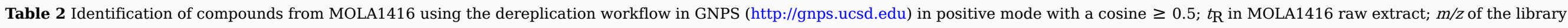

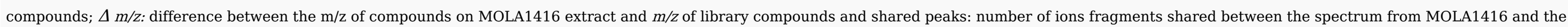
library spectra.

\begin{tabular}{|c|c|c|c|c|c|c|c|c|c|}
\hline & Identification & $\begin{array}{c}t_{R} \\
(\min )\end{array}$ & $m / z$ & $\Delta m / z$ & Cosine & $\begin{array}{l}\text { Shared } \\
\text { peaks }\end{array}$ & Chemical family & Sources & References \\
\hline 1 & $\begin{array}{l}\text { 3-(3,4-Dihydroxyphenyl)-8- } \\
\text { hydroxyisochromen-1-one }\end{array}$ & 29.23 & 271.06 & 1.849 & 0.60 & 6 & isocoumarin & $\begin{array}{l}\text { Botrichium lanuginosum, Hydrangea macrophylla } \\
\text { var. thunbergii }\end{array}$ & (Zhang et al., 2009) \\
\hline 2 & Genistein & 12.47 & 271.20 & 0.420 & 0.52 & 6 & isoflavone & Cytisus sp. & (Pereira et al., 2012; Raja et al., 2007) \\
\hline 3 & 10,11-Dehydrocurvularin & 33.71 & 291.13 & 1.905 & 0.54 & 6 & $\begin{array}{l}\text { fungal } \\
\text { phytotoxin }\end{array}$ & Aspergillus terreus & (Xu et al., 2013) \\
\hline 4 & 8-Oxoerythraline epoxide & 4.43 & 296.10 & 0.950 & 0.55 & 7 & alkaloïd & Erytrhina verna & (Callejon et al., 2014) \\
\hline 5 & Betapar & 32.17 & 373.16 & 1.924 & 0.61 & 6 & glucocorticoïd & Synthesis & (Fernández et al., 2003) \\
\hline 6 & Budesonide & 32.60 & 431.24 & 0.917 & 0.52 & 6 & glucocorticoïd & Synthesis & (Thalén and Brattsand, 1979) \\
\hline 7 & Prednisone & 37.99 & 359.19 & 1.946 & 0.54 & 9 & glucocorticoïd & Synthesis & (Li et al., 2009) \\
\hline 8 & Trinexapac & 2.55 & 225.08 & 1.764 & 0.69 & 6 & $\begin{array}{l}\text { cyclohexane- } \\
\text { dione }\end{array}$ & Synthesis & (Cooper and Storey, 2006) \\
\hline 9 & Glycocholic acid & 28.30 & 466.00 & 0.040 & 0.84 & 7 & sterol & Rat hepatocytes & (Iga and Klaassen, 1982) \\
\hline 10 & L-arginine & 2.64 & 176.12 & 1.340 & 0.75 & 6 & amino acid & Many sources (plants, fungi, bacteria, Ascidia, etc.) & $\begin{array}{l}\text { (Diak, 1977; Shan et al., 2010; Work, } \\
\text { 1949) }\end{array}$ \\
\hline 11 & cyclo-(D-Trp, L-Pro) & 20.74 & 284.14 & 0.059 & 0.91 & 8 & \multirow[t]{12}{*}{ diketopiperazine } & \multirow[t]{12}{*}{ Many sources (sponges, fungi, etc.) } & \multirow{12}{*}{$\begin{array}{l}\text { (Cho et al., 2012; Huang et al., 2010; } \\
\text { Kelecom, 2002) }\end{array}$} \\
\hline 12 & cyclo-(L-Trp, L-Pro) & 22.54 & 284.14 & 0.089 & 0.91 & 7 & & & \\
\hline 13 & cyclo-(L-Leu, L-Pro) & 18.15 & 211.14 & 0.033 & 0.96 & 8 & & & \\
\hline 14 & cyclo-(L-Phe, D-Pro) & 22.15 & 245.13 & 0.008 & 0.78 & 7 & & & \\
\hline 15 & cyclo-(L-Tyr, L-Pro) & 13.77 & 261.12 & 0.037 & 0.75 & 7 & & & \\
\hline 16 & cyclo-(Phe, 4-hydroxy-Pro) & 15.84 & 261.12 & 0.034 & 0.83 & 7 & & & \\
\hline 17 & cyclo-(Asn, Leu) & 11.99 & 228.13 & 1.713 & 0.74 & 6 & & & \\
\hline 18 & cyclo-(L-Pro, L-Val) & 15.67 & 197.13 & 0.022 & 0.96 & 7 & & & \\
\hline 19 & cyclo-(Leu, Leu) & 25.25 & 227.17 & 0.066 & 0.95 & 6 & & & \\
\hline 20 & cyclo-(Leu, Phe) & 25.66 & 261.16 & 0.519 & 0.94 & 8 & & & \\
\hline 21 & cyclo-(Val, Leu) & 22.62 & 213.16 & 0.219 & 0.93 & 8 & & & \\
\hline 22 & cyclo-(Val, Phe) & 23.94 & 247.14 & 0.103 & 0.94 & 6 & & & \\
\hline
\end{tabular}




\begin{tabular}{|l|l|l|l|l|l|l|}
\hline 23 & cyclo-(gly, L-Phe) & 14.47 & 205.07 & 0.026 & 0.98 & 8 \\
\hline 24 & cyclo-[(L-4-hydroxy-Pro)-L-Leu] & 16.05 & 227.14 & 0.358 & 0.92 & 8 \\
\hline 25 & cyclo-[Tyr-(4-hydroxy-Pro)] & 10.61 & 277.12 & 0.047 & 0.93 & 10 \\
\hline
\end{tabular}

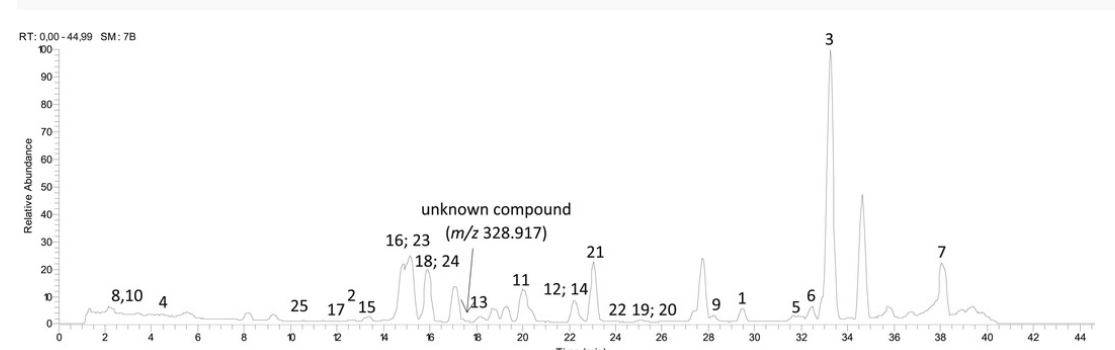

Fig. 2 Annotated mass spectrum in positive mode of MOLA1416 raw extracts. Numbers correspond to compounds identified by the dereplication workflow using GNPS (Table 2).

alt-text: Fig. 2 

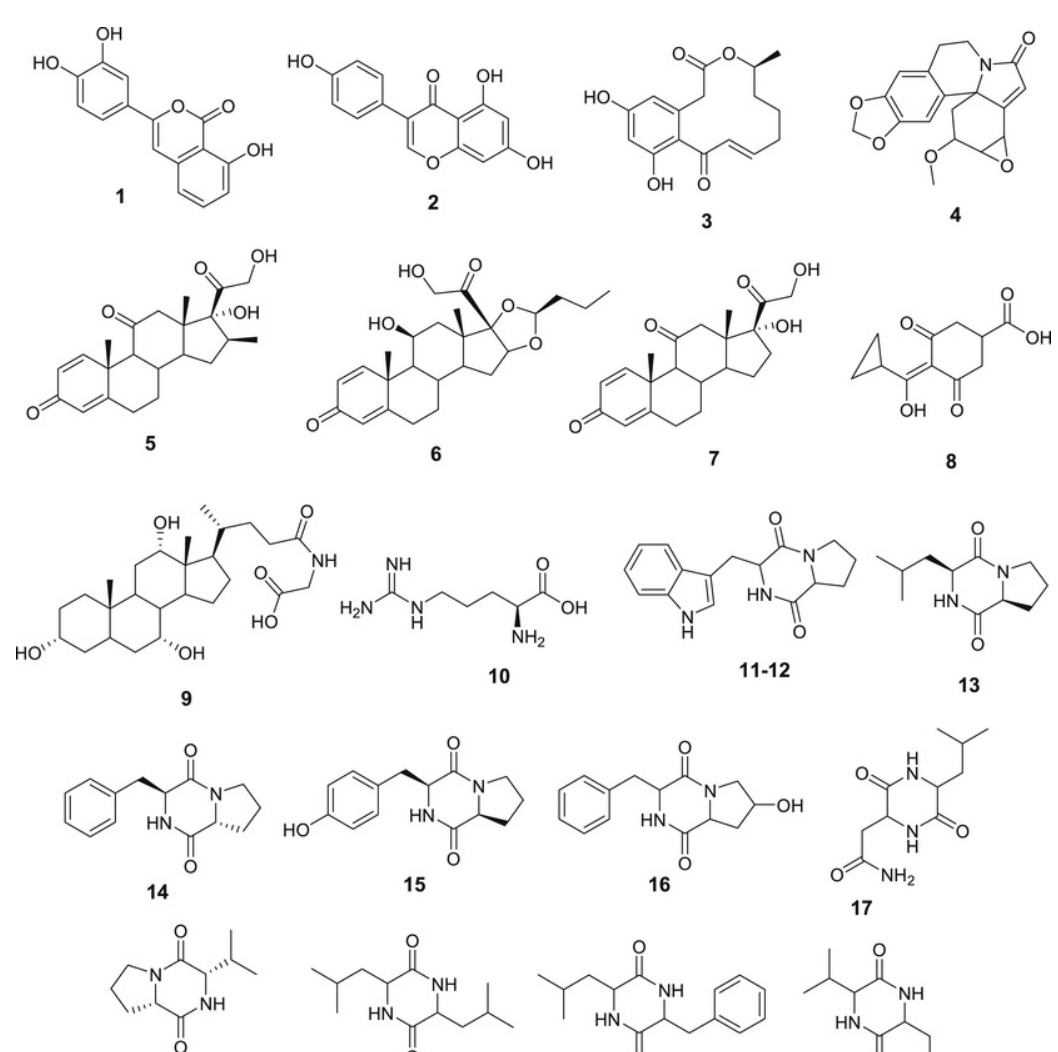

$\mathrm{NH}^{\mathrm{O}}$
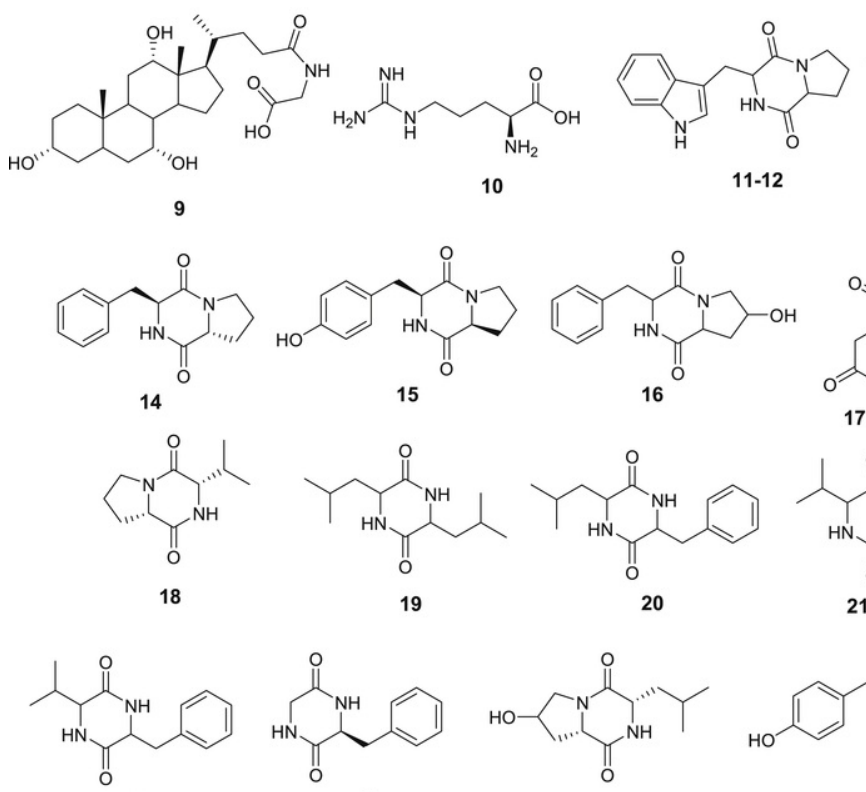

22

11-12

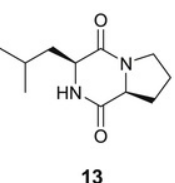

13
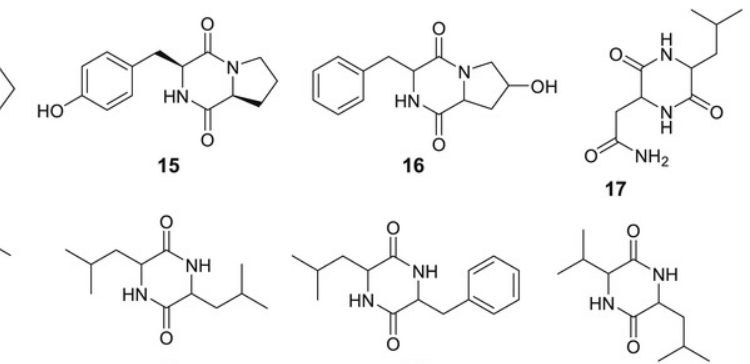

20
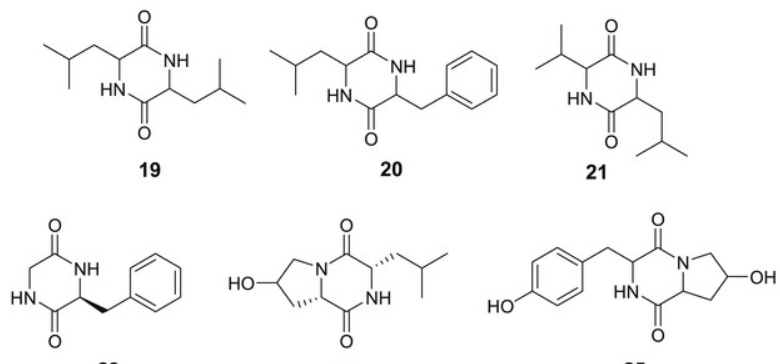

Fig. 3 Chemical structure of MOLA 1416 metabolites identified by the dereplication workflow in the positive mode using GNPS (Number relative to those of Table 2).

alt-text: Fig. 3

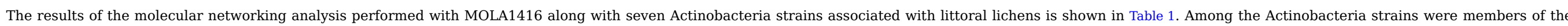

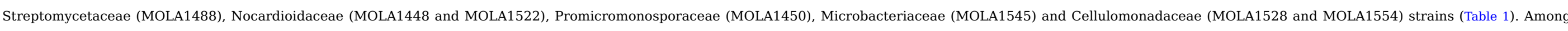

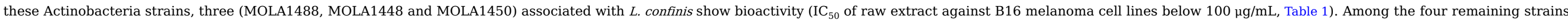

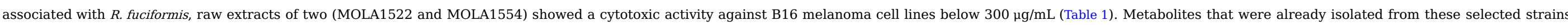
are listed in Table 1.

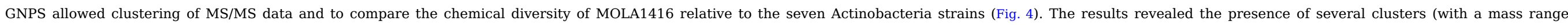

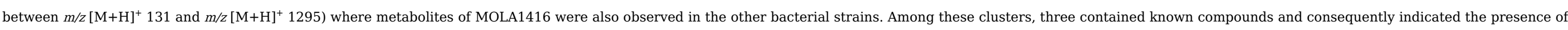

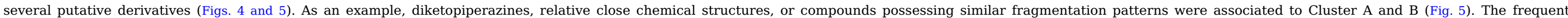




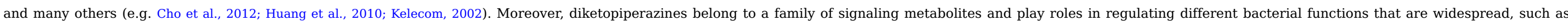
antibiotic biosynthesis, production of virulence factors, exopolysaccharide biosynthesis and bacterial swarming among others (Brelles-Mario and Bedmar, 2001)

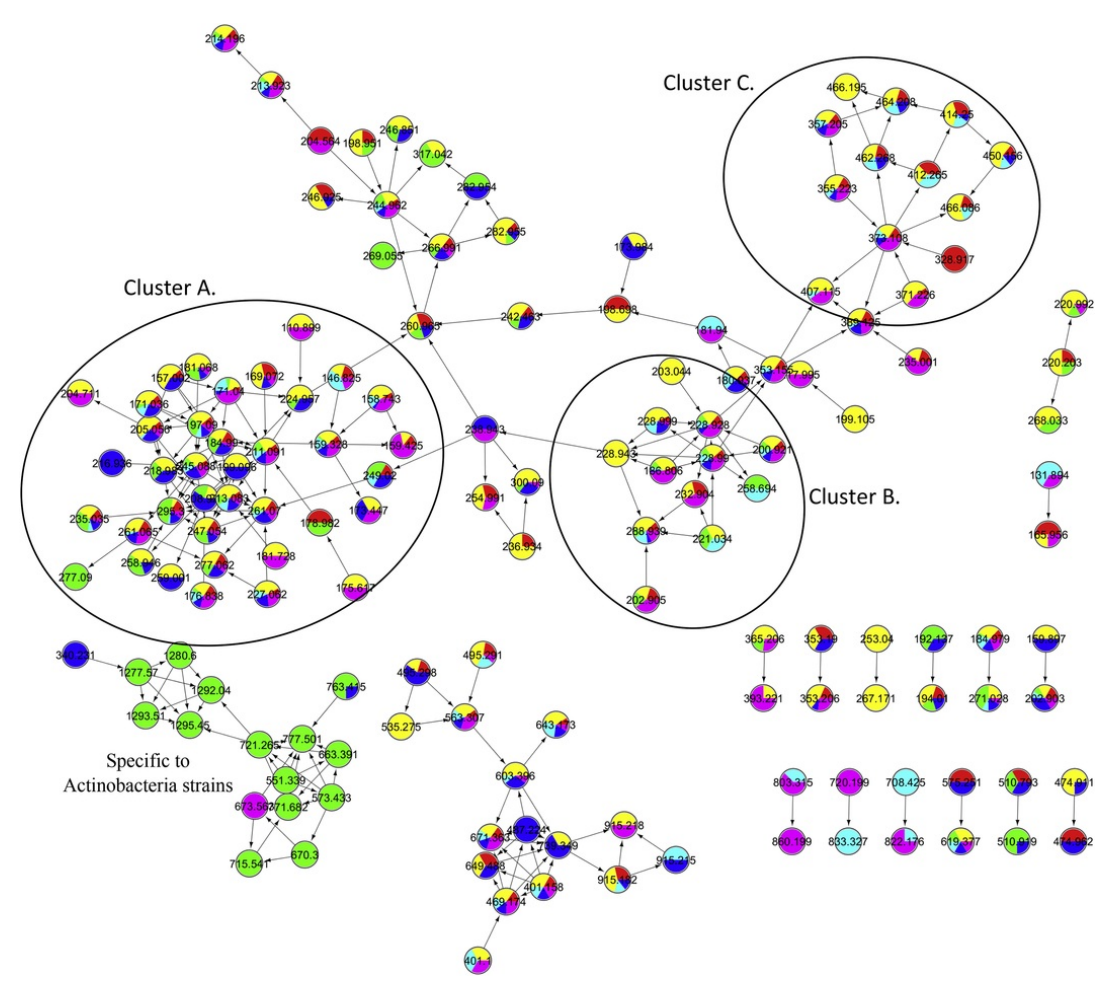

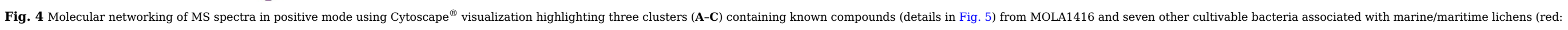

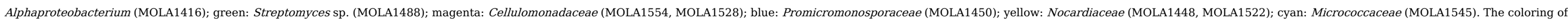

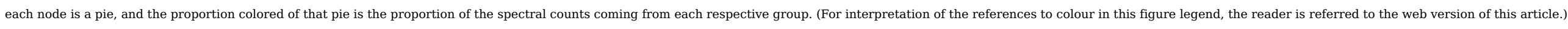



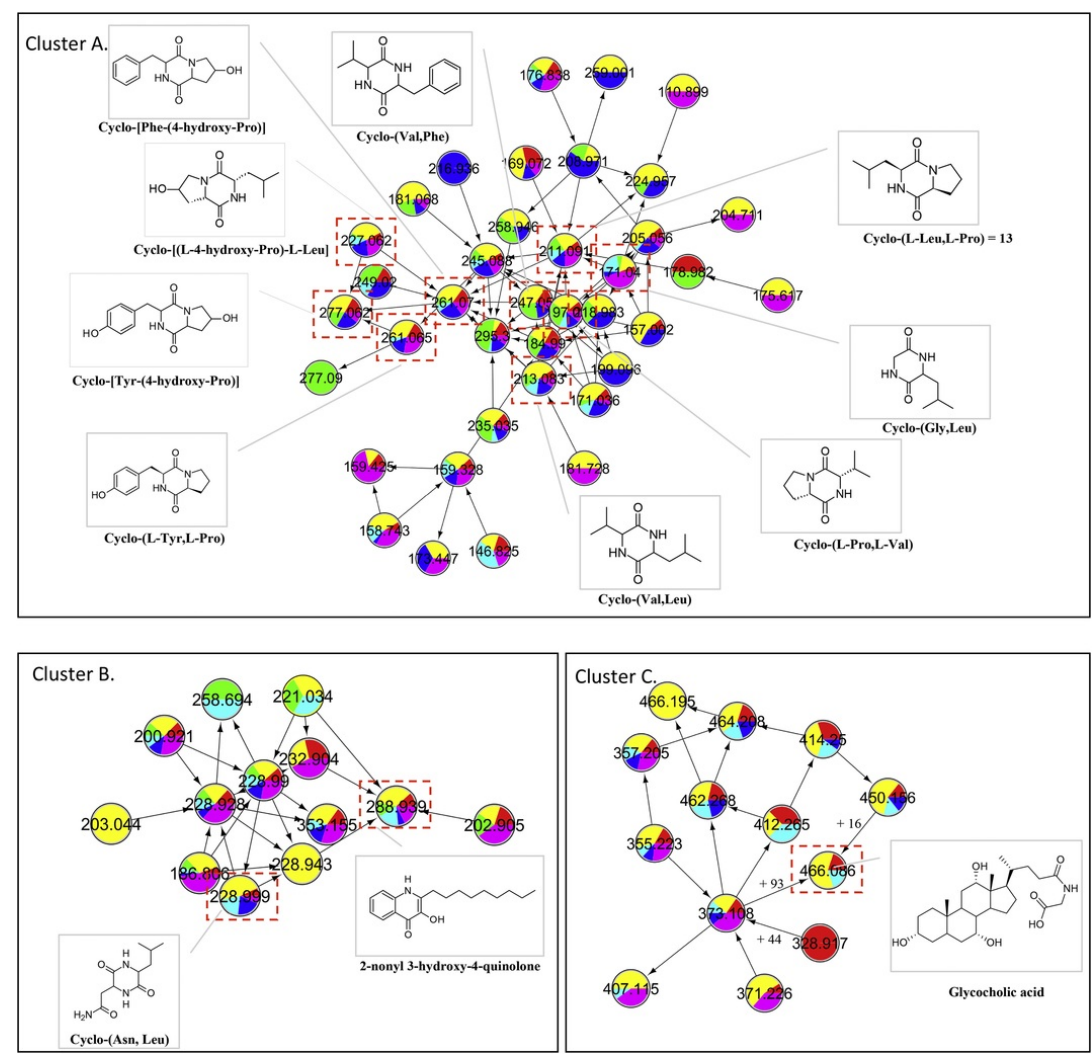

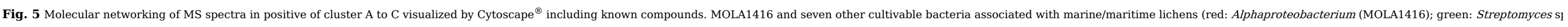

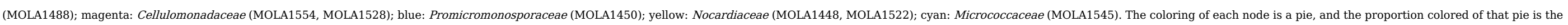
proportion of the spectral counts coming from each respective group. (For interpretation of the references to colour in this figure legend, the reader is referred to the web version of this article.)

\section{alt-text: Fig. 5}

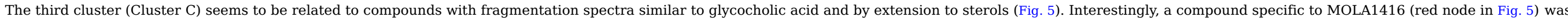

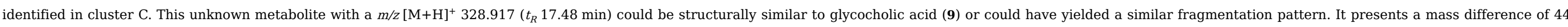

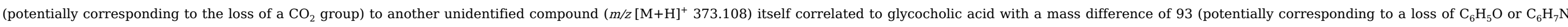
group) (Fig. 5). However, without any additional information, we hypothesize this compound from MOLA1416 belongs to a family putatively identified as sterols.

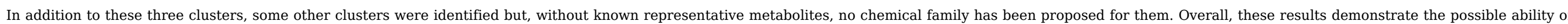

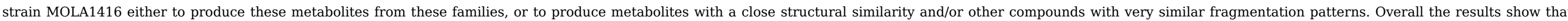

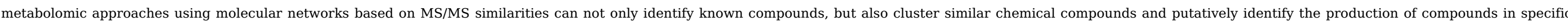
chemical families accelerating dereplication of molecules produced by different biological sources.

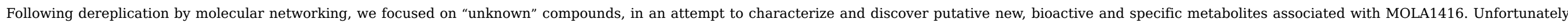

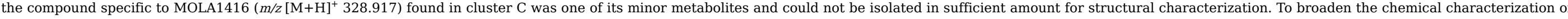
the strain we then focused on the more "apolar" compounds identified in the PDA chromatogram (Fig. 1A) and that were not ionized under our analytical conditions. 


\subsection{Isolation process and chemical identification}

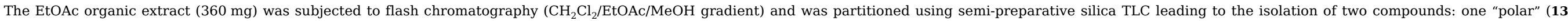

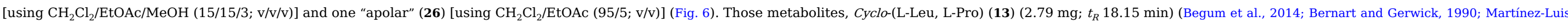

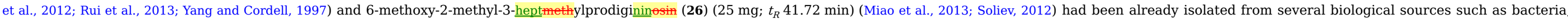

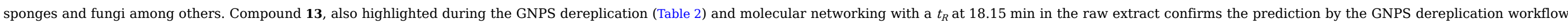

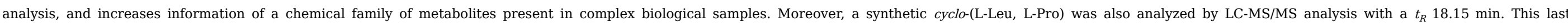
information inferred the $L, L$ configuration of compound 13. Structural characteristics (NMR data) for these two compounds (13 and 26) are available as supplementary data files (Figs. S2-S3).
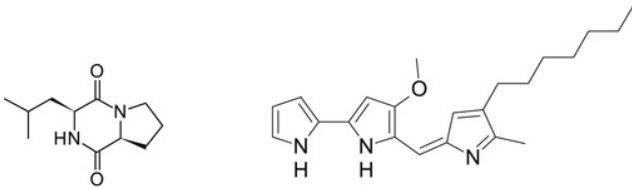

(13)

(26)

Fig. 6 Chemical structure of compounds isolated (13 and 26): 13. Cyclo-(L-Leu,L-Pro) and 26. 6-methoxy-2-methyl-3-metheptylprodigininosin.

alt-text: Fig. 6

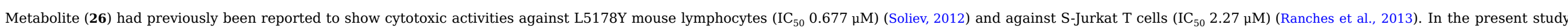

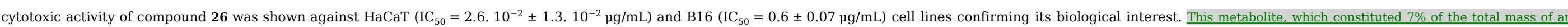

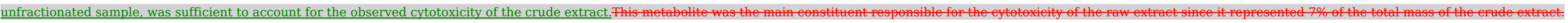

\section{Conclusion}

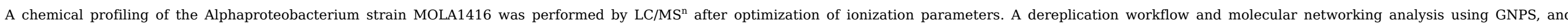

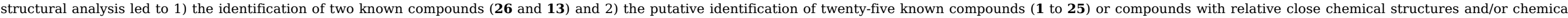

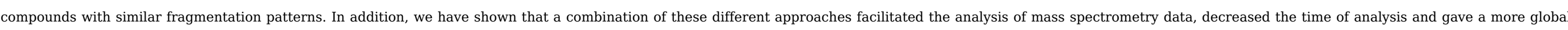

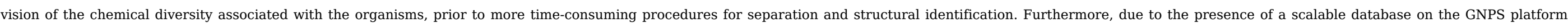

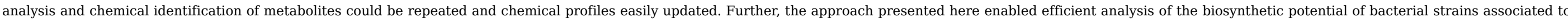

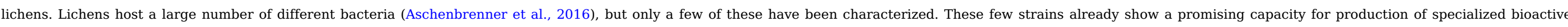
compounds. We argue that lichens are a treasure chest for bacterial potential which has to be exploited. In the future, we plan to extend these studies to lichens from another environments.

\section{Experimental}

\subsection{Chemicals and reagents}

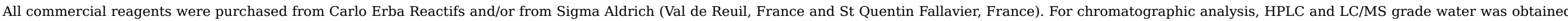
using an EasyPure (Barnstead, USA) water purification system. Deuterated solvents were purchased from Euriso-top (Gif-sur-Yvette, France).

\subsection{Microorganism}

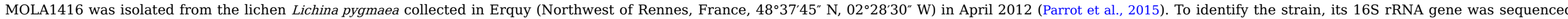

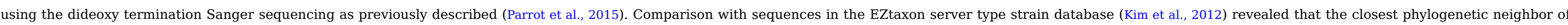

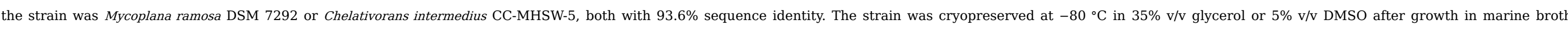

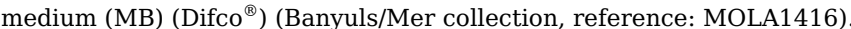




\subsection{Culture, extraction, isolation and purification procedure}

\subsubsection{Fermentation of strain MOLA1416}

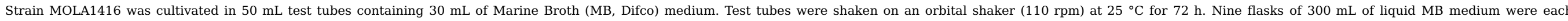

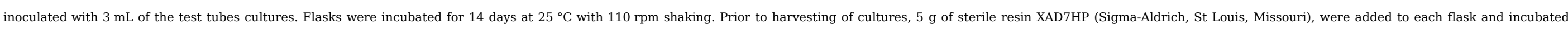

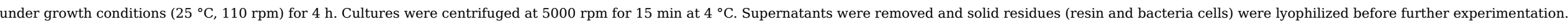

\subsubsection{Production of raw extracts of strain MOLA1416}

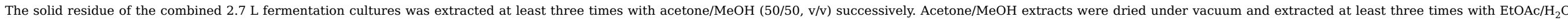

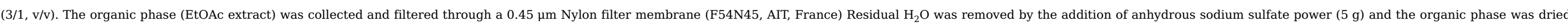

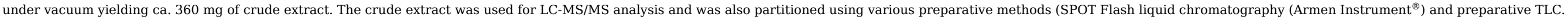

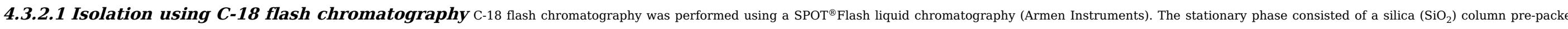

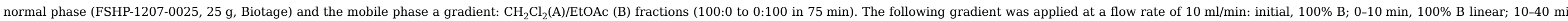
50\% B linear; 40-45 min 50\% B linear; 45-75 min, 0\% B linear followed by washing the column with 100\% MeOH for 30 min. 105 fractions (f1-f105) of 10 mL each were collected.

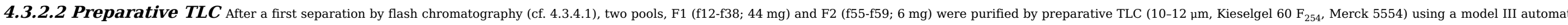
TLC (Camag ${ }^{\circledR}$ ). Two systems solvents were applied: $\mathrm{CH}_{2} \mathrm{Cl}_{2} / \mathrm{EtOAc}\left(95 / 5\right.$, v/v) for $\mathrm{F} 1$ and $\mathrm{CH}_{2} \mathrm{Cl}_{2} / \mathrm{EtOAc} / \mathrm{MeOH}(15 / 15 / 3$, v/v/v) for F2 and led to the isolation of two compounds (13 and 26).

\subsubsection{Fermentation and extraction in small scale (other strains)}

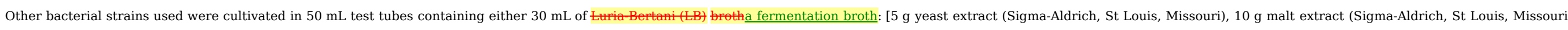

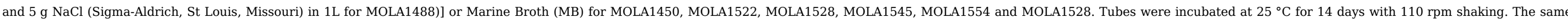
extraction procedure was applied (cf. 4.3.2) and EtOAc extracts were obtained for all seven strains. These crude EtOAc extracts were used for LC-MS/MS analysis.

\subsection{LC-ESI-MS/MS analysis}

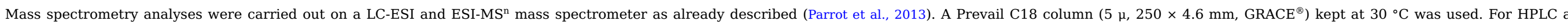

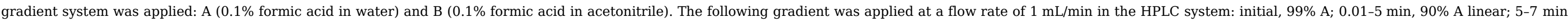

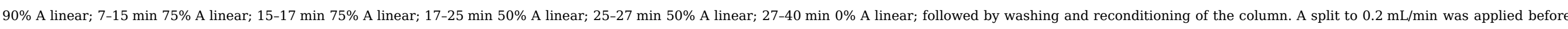

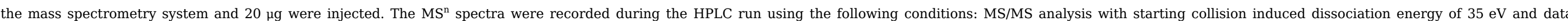
analyses were performed using Xcalibur v1.0

\subsubsection{Dereplication workflow and molecular networking}

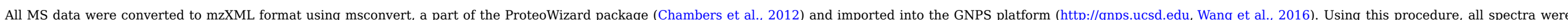

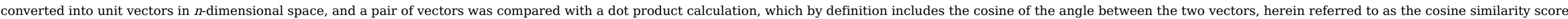

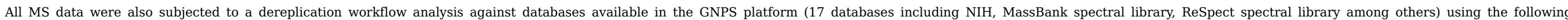
parameters: score threshold 0.5, minimum intensity peak 50, parent mass tolerance $2.0 \mathrm{Da}$, ion tolerance $0.5 \mathrm{Da}$, minimum matched peaks 6 and filter standard deviation intensity of 2.0 .

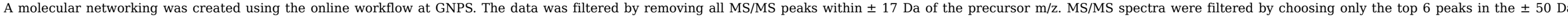

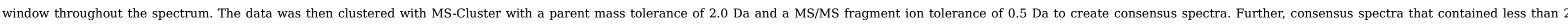

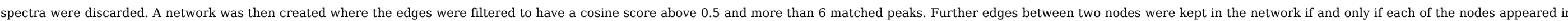

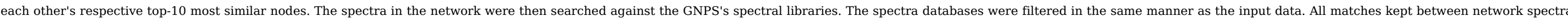


Mass spectrometry data of all EtOAc bacterial extracts used in this study were added to the Public Massive datasets in GNPS (Massive ID MSV000078947).

\subsection{NMR analysis}

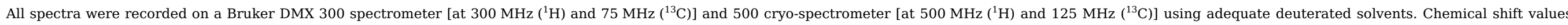

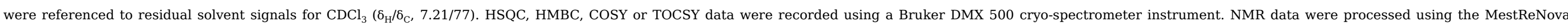
version 1.3 software.

\subsection{HRMS measurements}

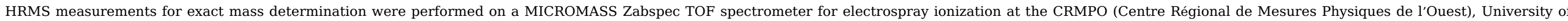
Rennes 1 .

\subsection{Characteristics of isolated compounds}

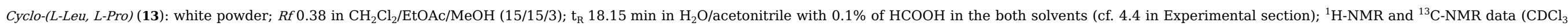
$125 \mathrm{MHz}$ ) as described in the literature (Rui et al., 2013); HRESIMS $\mathrm{m} / \mathrm{z} 233.126057[\mathrm{M}+\mathrm{Na}]^{+}$(calcd for $\mathrm{C}_{11} \mathrm{H}_{18} \mathrm{~N}_{2} \mathrm{O}_{2} \mathrm{Na}$, 233.124952).

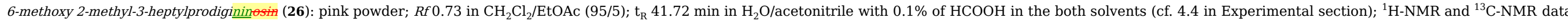
$\left(\mathrm{CDCl}_{3}, 125 \mathrm{MHz}\right.$ ) as described in the literature (Soliev, 2012) HRESIMS $\mathrm{m} / \mathrm{z} 352.2384[\mathrm{M}+\mathrm{H}]^{+}$(calcd for $\mathrm{C}_{22} \mathrm{H}_{30} \mathrm{~N}_{3} \mathrm{O}, 352.23889$ ).

\subsection{Biological assays}

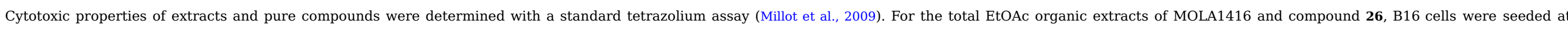

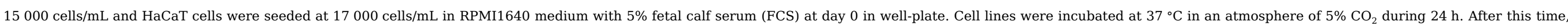

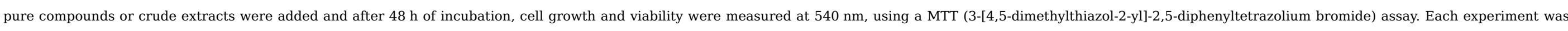
repeated at least three times.

\section{Acknowledgments}

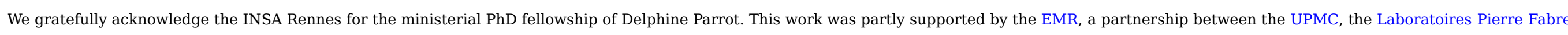

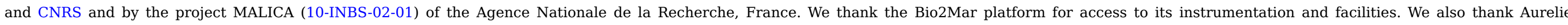

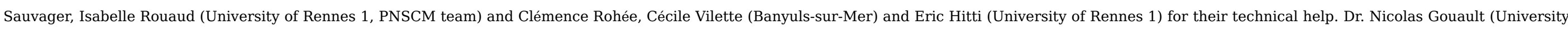

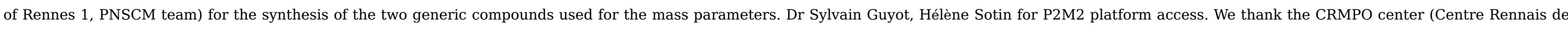

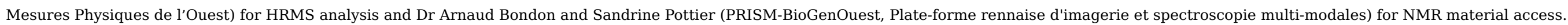

\section{Appendix A. Supplementary data}

Supplementary data related to this article can be found at https://doi.org/10.1016/j.phytochem.2017.10.005.

\section{Uncited reference}

Schneider et al., 2011.

\section{References}

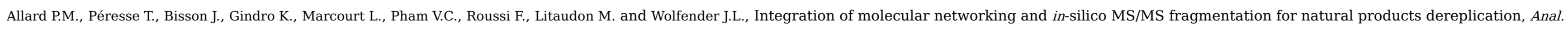


Chem. 88, 2016, 3317-3323, https://doi.org/10.1021/acs.analchem.5b04804.

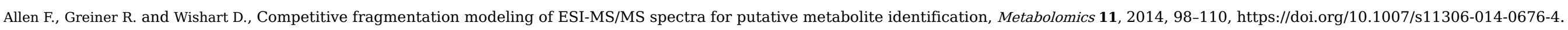
Aschenbrenner I.A., Cernava T., Berg G. and Grube M., Understanding microbial multi-species symbioses, Front. Microbiol. 7, 2016, 180, https://doi.org/10.3389/fmicb.2016.00180.

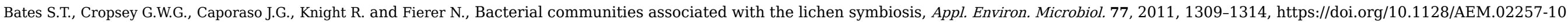
Barazani O. and Friedman J., Is IAA the major root growth factor secreted from plant-growth-mediating bacteria?, J. Chem. Ecol. 25, 1999, 2397-2406, https://doi.org/10.1023/a1020890311499.

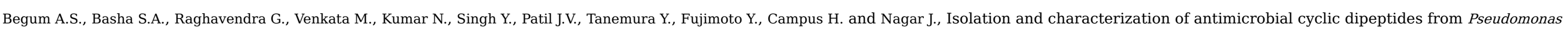
fluorescens and their efficacy on sorghum grain mold fungi, Chem. Biodivers. 11, 2014, 92-100.

Bernart M. and Gerwick W.H., 3-(Hydroxyacetyl)indole, a plant growth regulator from the Oregon red alga Prionitis lanceolata, Phytochem. Anal. 29, 1990, 3697-3698.

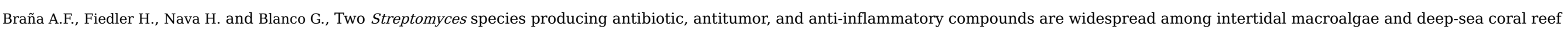
invertebrates from the central cantabrian sea, Microb. Ecol. 69, 2015, 512-524, https://doi.org/10.1007/s00248-014-0508-0.

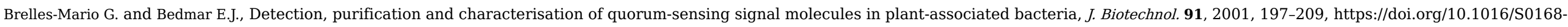
1656(01)00330-3.

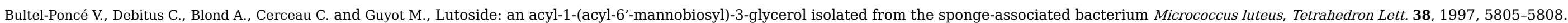

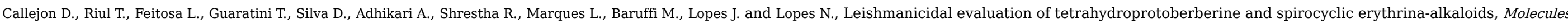
19, 2014, 5692-5703, https://doi.org/10.3390/molecules19055692.

Cao M., Fraser K. and Rasmussen S., Computational analysis of spectral trees from electrospray multi-stage mass spectrometry to aid metabolite identification, Metabolites 3, 2013, 1036-1050, https://doi.org/10.3390/metabo3041036.

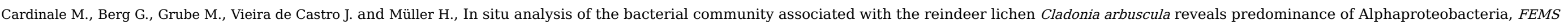
Microbiol. Ecol. 66, 2008, 63-71, https://doi.org/10.1111/j.1574-6941.2008.00546.x.

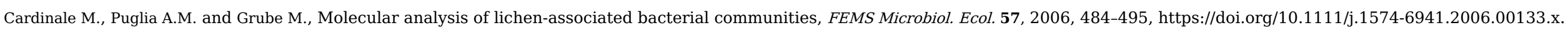

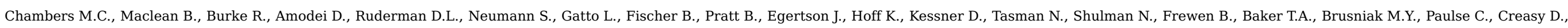

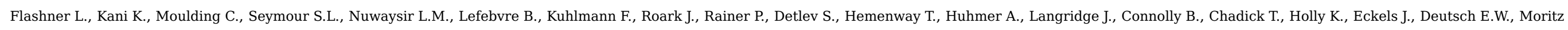

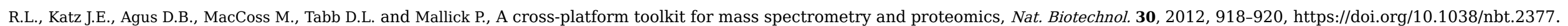

Cheenpracha S., Vidor N.B., Yoshida W.Y., Davies J. and Chang L.C., Coumabiocins A-F, aminocoumarins from an organic extract of Streptomyces sp. L-4-4, J. Nat. Prod. 73, 2010, 880-884.

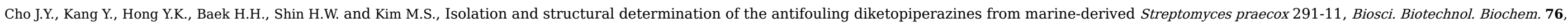

2012, 1116-1121, https://doi.org/10.1271/bbb.110943.

Cooper, R., Storey, R., 2006. Plant growth regulation compositions and methods using gibberellin biosynthesis inhibitor combinations. U.S. Patent No. 7,135,435.

Davies J., Wang H., Taylor T., Warabi K., Huang X.H. and Andersen R.J., Uncialamycin, a new enediyne antibiotic, Org. Lett. 7, 2005, 5233-5236, https://doi.org/10.1021/ol052081f.

Dellweg H., Kurz J., Pflüger W., Schedel M., Vobis G. and Wünsche C., Rodaplutin, a new peptidylnucleoside from Nocardioides albus, J. Antibiot. Tokyo 41, $1988,1145-1147$.

Diak J., The study of some compounds biosynthesized by Naematoloma fasciculare (Huds ex Fr.) P. Karst. Part I. Analysis in vitro, Pol. J. Pharmacol. Pharm. 27, 1977, 235-241.

Dührkop K., Shen H., Meusel M., Rousu J. and Böcker S., Searching molecular structure databases with tandem mass spectra using CSI: FingerID, Proc. Natl. Acad. Sci. 112, 2015, 12580-12585, 
Fernández D., Vega D. and Ellena J.A., 17a,21-Dihydroxy-16ß-methyl-pregna-1,4-diene-3,11,20-trione (meprednisone), Acta Crystallogr. Sect. C Cryst. Struct. Commun. 59, 2003, 187-189, https://doi.org/10.1107/S0108270103003184.

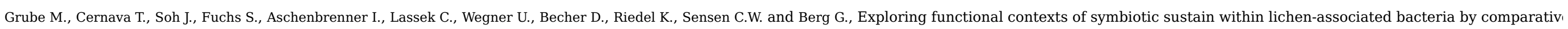
omics, ISME J. 2014, 1-13, https://doi.org/10.1038/ismej.2014.138.

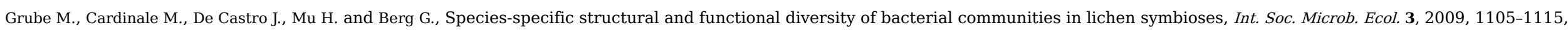
https://doi.org/10.1038/ismej.2009.63.

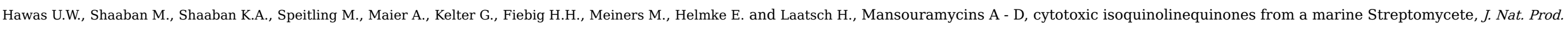
72, 2009, 2120-2124.

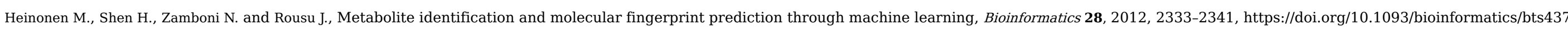

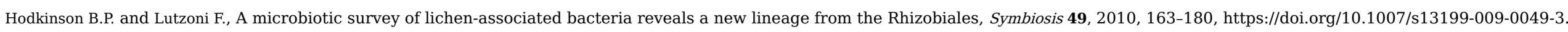

Huang R., Ding Z., Long Y., Zhao J., Li M., Cui X. and Wen M., A new isoflavone derivative from Streptomyces sp. YIM 3536, Chem. Nat. Compd. 48, 2013, 856-858.

Huang R., Zhou X., Xu T., Yang X. and Liu Y., Diketopiperazines from marine organisms, Chem. Biodivers. 7, 2010, $2809-2829$.

Hufsky F., Scheubert K. and Böcker S., Computational mass spectrometry for small-molecule fragmentation, TrAC Trends Anal. Chem. 53, 2014, 41-48, https://doi.org/10.1016/j.trac.2013.09.008.

Iga T. and Klaassen C.D., Uptake of bile acids by isolated rat hepatocytes, Biochem. Pharmacol. 31, 1982, 211-216.

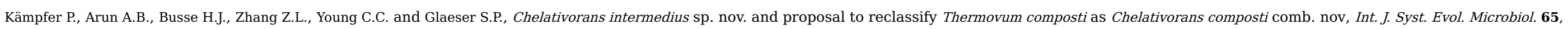
2015, 1646-1652, https://doi.org/10.1099/ijs.0.000155.

Kelecom A., Secondary metabolites from marine microorganisms, An. Acad. Bras. Cienc. 74, 2002, 151-170.

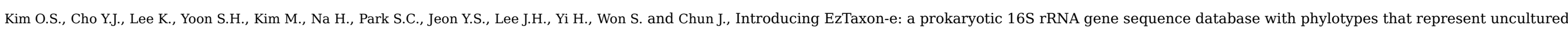
species, Int. J. Syst. Evol. Microbiol. 65, 2012, 716-721.

Li B., Chen G., Bai J., Jing Y.K. and Pei Y.H., A bisamide and four diketopiperazines from a marine-derived Streptomyces sp, J. Asian Nat. Prod. Res. 13, 2011, 1146-1150.

Li F., Jin L., Han J., Wei M. and Li C., Synthesis and controlled release properties of prednisone intercalated Mg-Al layered double hydroxide composite, Ind. Eng. Chem. Res. 48, 2009, 5590-5597, https://doi.org/10.1021/ie900043r.

Martínez-Luis S., Gómez J.F., Spadafora C., Guzmán H.M. and Gutiérrez M., Antitrypanosomal alkaloids from the marine bacterium Bacillus pumilus, Molecules 17, 2012, 11146-11155, https://doi.org/10.3390/molecules170911146.

Martins M.B. and Carvalho I., Diketopiperazines: biological activity and synthesis, Tetrahedron 63, 2007, 9923-9932, https://doi.org/10.1016/j.tet.2007.04.105.

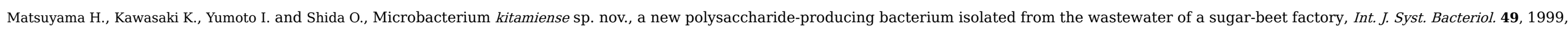
1353-1357.

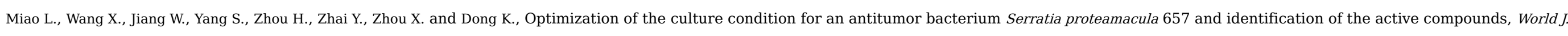
Microbiol. Biotechnol. 29, 2013, 855-863, https://doi.org/10.1007/s11274-012-1240-x.

Millot M., Tomasi S., Studzinska E., Rouaud I. and Boustie J., Cytotoxic constituents of the lichen Diploicia canescens, J. Nat. Prod. 33, 2009, $2177-2180$. 
Motohashi K., Takagi M., Yamamura H., Hayakawa M. and Shin-ya K., A new angucycline and a new butenolide isolated from lichen-derived Streptomyces spp, J. Antibiot. Tokyo 63, 2010, 545-548,

https://doi.org/10.1038/ja.2010.94.

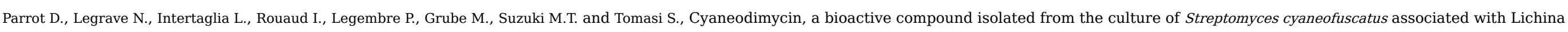
confinis, Eur. J. Org. Chem. 2016b, 3977-3982, https://doi.org/10.1002/ejoc.201600252.

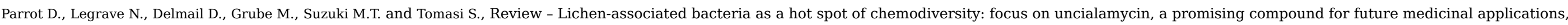
Planta Med. 2016a, https://doi.org/10.1055/s-0042-105571.

Parrot D., Anthony Babu S., Intertaglia L., Grube M., Tomasi S. and Suzuki M.T., Littoral lichens as a novel source of potentially bioactive Actinobacteria, Sci. Rep. 5, $2015,15839$.

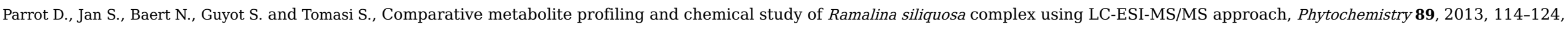
https://doi.org/10.1016/j.phytochem.2013.02.002.

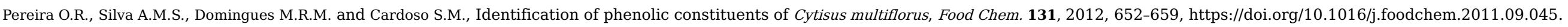

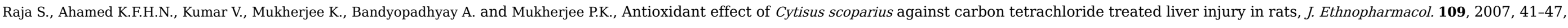
https://doi.org/10.1016/j.jep.2006.06.012.

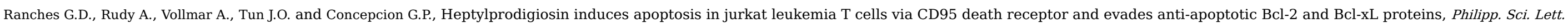
6, 2013, 153-167.

Rohmer M., Bouvier-Nave P. and Ourisson G., Distribution of hopanoid triterpenes in prokaryotes, Microbiology 130, 1984, 1137-1150, https://doi.org/10.1099/00221287-130-5-1137.

Rui H., Bochu W., Wakimoto T., Manyuan W., Liancai Z. and Ikuro A., Cyclopeptides from metagenomic library of a Japanese marine sponge, J. Braz. Chem. Soc. 24, 2013, 1926-1932.

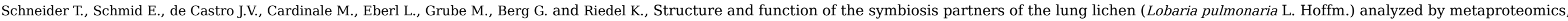
Proteomics 11, 2011, 2752-2756.

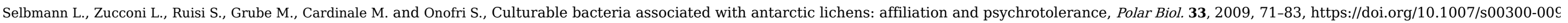
0686-2.

Shan Y., Zhou J., Zhao H.G., Feng X., Dong Y. and Xia B., Amino-acid and mineral composition of Stellaria media, Chem. Nat. Compd. 46, 2010, 562-563.

Shashkov A., Tul'skaya E., Evtushenko L. and Naumova I., A teichoic acid of Nocardioides albus VKM Ac-805(T) cell walls, Biochemistry 64, 1999, 1305-1309.

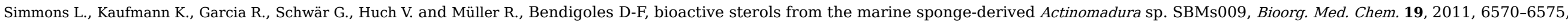
https://doi.org/10.1016/j.bmc.2011.05.044.

Soliev A.B., Pigmented Bioactive Compounds from Marine Bacteria and Their Mechanisms of Action Involved in Cytotoxicity, 2012, Université de Kochi; Japon, 120.

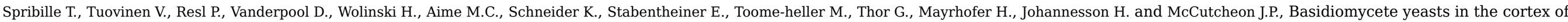
ascomycete macrolichens, Science 353, 2016, 488-492.

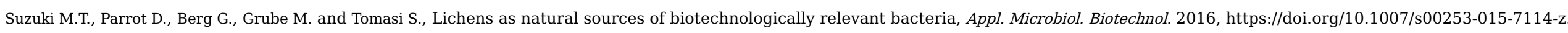

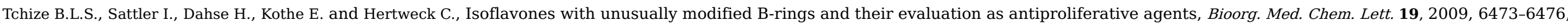
https://doi.org/10.1016/j.bmcl.2009.08.084.

Thalén A. and Brattsand R., Synthesis and anti-inflammatory properties of budesonide, a new non-halogenated glucocorticoid with high local activity, Arzneimittelforschung 29, 1979, 1687-1690. 


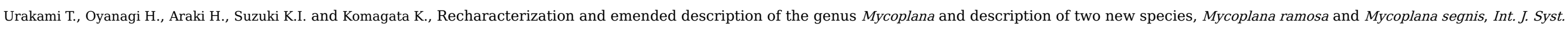

Bacteriol. 40, 1990, 434-442, https://doi.org/10.1099/00207713-40-4-434.

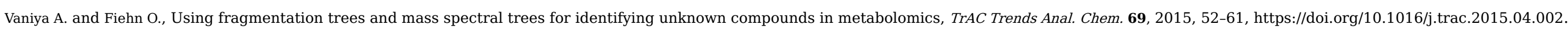

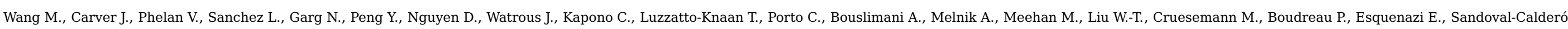

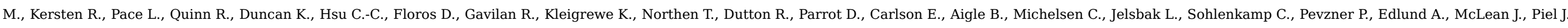

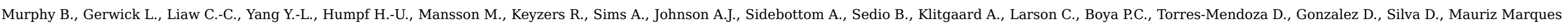

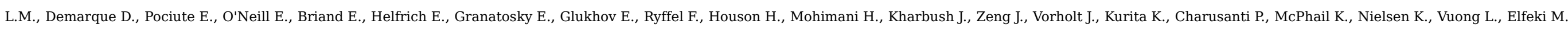

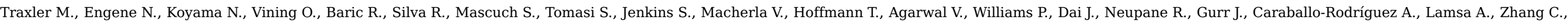

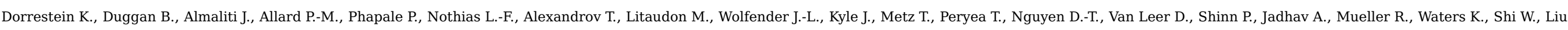

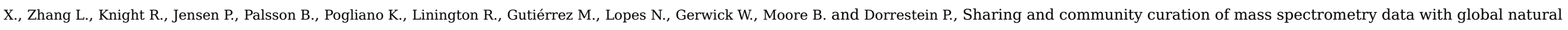
products social molecular networking, Nat. Biotechnol. 34, 2016, 828-837.

Wei J.H., Yin X. and Welander P.V., Sterol synthesis in diverse bacteria, Front. Microbiol. 7, 2016, 1-19, https://doi.org/10.3389/fmicb.2016.00990.

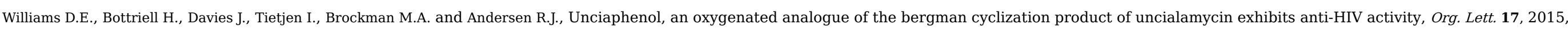
5304-5307, https://doi.org/10.1021/acs.orglett.5b02664

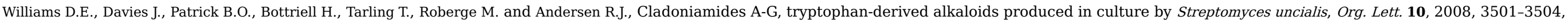
https://doi.org/10.1021/ol801274c.

Work E., Chromatographic investigations of amino acids from micro-organisms. The amino acids of Corynebacterium diphteriae, Biochim. Biophys. Acta 3, 1949 , 400-411.

Wu S.J., Fotso S., Li F., Qin S. and Laatsch H., Amorphane sesquiterpenes from a marine Streptomyces sp, J. Nat. Prod. 70, 2007, $304-306$.

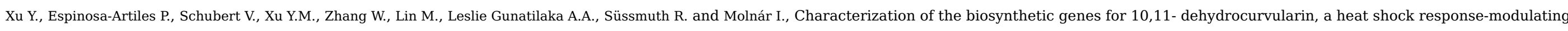
anticancer fungal polyketide from Aspergillus terreus, Appl. Environ. Microbiol. 79, 2013, 2038-2047, https://doi.org/10.1128/AEM.03334-12.

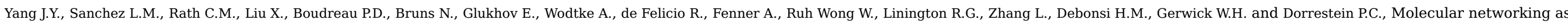
dereplication strategy, NIH J. Nat. Prod. 76, 2014, 1686-1699, https://doi.org/10.1021/np400413s.

Yang S. and Cordell G.A., Metabolism studies of indole derivatives using a staurosporine producer, Streptomyces staurosporeus, J. Nat. Prod. 60, 1997 , 44-48.

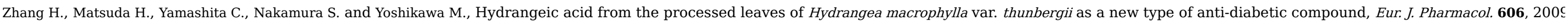
255-261, https://doi.org/10.1016/j.ejphar.2009.01.005.

\section{Appendix A. Supplementary data}

The following is the supplementary data related to this article:

Multimedia Component 1

mmc1

alt-text: mmc1

Graphical abstract 


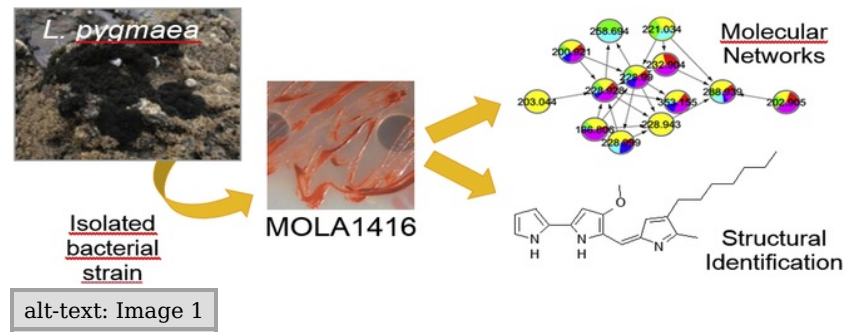

\section{Highlights}

- Chemical investigation of a Rhizobiales strain associated with Lichina pygmaea.

- Dereplication workflow based on MS/MS signatures and molecular networks were used.

- 25 putative known compounds were revealed.

- 2 metabolites were isolated and structurally identified.

\section{Queries and Answers}

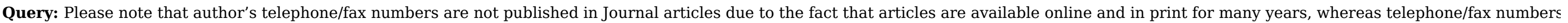
are changeable and therefore not reliable in the long term.

Answer: It is ok

Query: Could you please provide the grant number for (1) Laboratoires Pierre Fabre, (2) EMR and (3) UPMC, if any?

Answer: No grant number

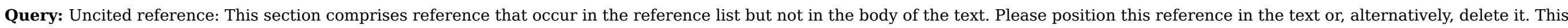
reference not dealt with will be retained in this section. Thank you.

Answer: This reference must be removed

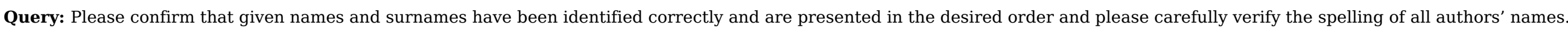

Answer: Yes

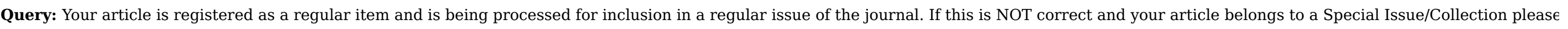
contact f.woodham-kay@elsevier.com immediately prior to returning your corrections.

Answer: Yes 